\title{
The Contribution of Financial Literation and Human Capital In Improving The Performance of Village-Owned Business Agencies
}

\author{
M. Ihsan ${ }^{1 *}$, Burhanuddin Ladjin $^{1}$, Fatma $^{1}$, Arif Widyatama ${ }^{1}$, Tri Rahmat ${ }^{1}$ \\ 1 STIE Panca Bhakti Palu, Indonesia \\ *e-mail: moh_ihsan@stiepbpalu.ac.id
}

Article history: Received 15 December 2020; Accepted 31 March 2021; Available online 30 April 2021

\begin{abstract}
The purpose of this study is to examine the relationship between financial literacy and human capital on the performance of Village-Owned Enterprise. Village-Owned Enterprise has an important role in building the economy in the village. However, the condition that occurs is that there are still many conditions of rural community human resources, especially Village-Owned Enterprise officials, who do not have good management skills and financial

\section{Keywords:}

Financial literacy;

Human capital; Village-

Owned Enterprise

performance; Village-

owned enterprises;

Resource Based View literacy in managing Village-Owned Enterprise. This research uses explanatory research, research sites are in Sigi and Poso Regencies. The population of this research is the management of Village-Owned Enterprise in Sigi and Poso Regencies, amounting to around 300 people representing each village in Sigi and Poso Regencies. Based on the results of the questionnaire distribution, a sample of 75 Village-Owned Enterprise administrators in Sigi and Poso districts was obtained. Financial literacy in Sigi village and even more so in Poso district is still far from perfect, because Village-Owned Enterprise administrators in SIGI and Poso in general are unable to use village participation funds accountably. This is due to the weak capacity of Village-Owned Enterprise administrators in managing Village-Owned Enterprise planning, implementation and financial reporting. The results of this study prove that the human capital of Village-Owned Enterprise administrators has an effect on Village-Owned Enterprise performance. This indicates that the community, including VillageOwned Enterprise administrators, has the potential to innovate so that it will have an impact on VillageOwned Enterprise performance.
\end{abstract}

Copyright (c) Universitas Pendidikan Ganesha. All rights reserved.

\section{Introduction}

The purpose of this study is to examine the relationship between financial literacy and human capital on the performance of Village-Owned Enterprise. Village-Owned Enterprise has an important role in building the economy in the village. However, the condition that occurs is that there are still many conditions of rural community human resources, especially VillageOwned Enterprise officials, who do not have good management skills and financial literacy in managing Village-Owned Enterprise. An appropriate strategy is very important for every Village-Owned Enterprise management to have and implement. The strategies required by each Village-Owned Enterprise management will vary depending on the problems faced by each manager (Mabula \& Ping, 2018; Novi Yushita Amanita, 2017; Owusu et al., 2019; Sugiarti et al., 2019). This condition will vary considering the many different problems faced by each VillageOwned Enterprise manager in their Village-Owned Enterprise (Agyei et al., 2019; Djuwita \& 
Yusuf, 2018; Ye \& Kulathunga, 2019). The Panca Bhakti Palu College of Economics in organizing, since 2017 has committed to participate in building villages by assisting several villages that need guidance and development of village apparatus resources and Village-Owned Enterprise. Currently, there are 16 villages under the guidance of STIE Panca Bhakti Palu, which are spread across Sigi Regency and Poso Regency. According to data from the Community and Village Empowerment Agency of Central Sulawesi Province, there are 14 Village-Owned Enterprise in the target village area.

\section{Method}

This research is categorized as an explanatory research which explains the causal relationship between variables through hypothesis testing. This research focuses on scientific disclosure and explanation regarding the influence of the independent variable on the dependent variable. This research will also conduct mapping and investigate the factors that determine the performance of Village-Owned Enterprise. The research will be focused on testing empirically as well as mapping the factors that affect the performance of Village-Owned Enterprise.

The research will be carried out in several stages. The first stage, the researcher makes observations in the field and studies literature related to the problem / phenomenon to be studied. The second stage, the researcher formulates the research problem. The third stage is collecting data to answer the research problem. The fourth stage, the researcher use Linear regression to analyze the linkages and relationships between different research variables, namely the dependent variable and the independent variable by requiring data consisting of several groups of observation or measurement results. Analyze and process the data on the data that has been collected. The final stage, data interpretation and decision making by researchers. The population of this research is the management of Village-Owned Enterprise in Sigi and Poso Regencies, amounting to around 300 people representing each village in Sigi and Poso Regencies. Based on the results of the questionnaire distribution, a sample of 75 Village-Owned Enterprise administrators in Sigi and Poso districts was obtained.

\section{Result and Discussion}

Characteristics of respondents that are deemed necessary to be described in this study consist of gender, latest education and age. Characteristics of respondents based on gender are shown in Table 1.

Table 1.

Respondents based on gender

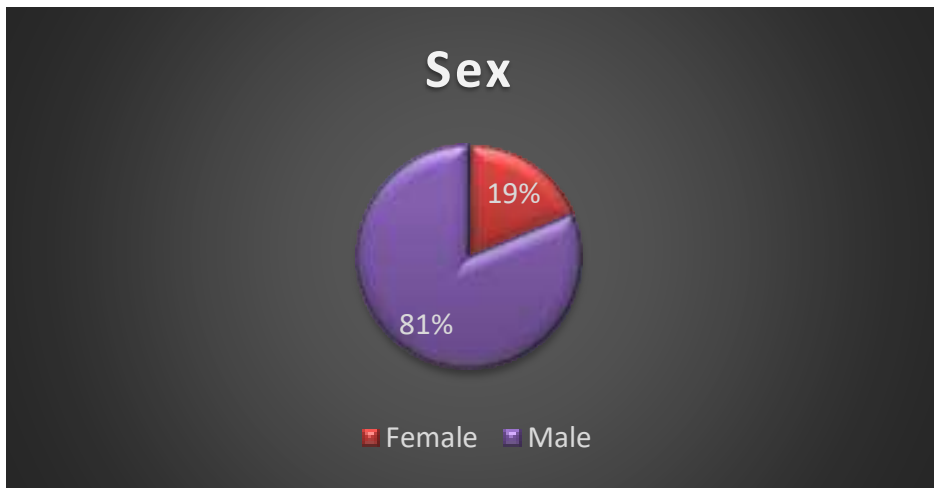


Table 1 shows that the respondents in this study consisted of 61 men (81\%) and 14 women (19\%). This shows that most Village-Owned Enterprise administrators in Sigi and Poso Districts are male. Characteristics of respondents based on the latest education can be seen in Table 2 .

Table 2.

Education level of respondents

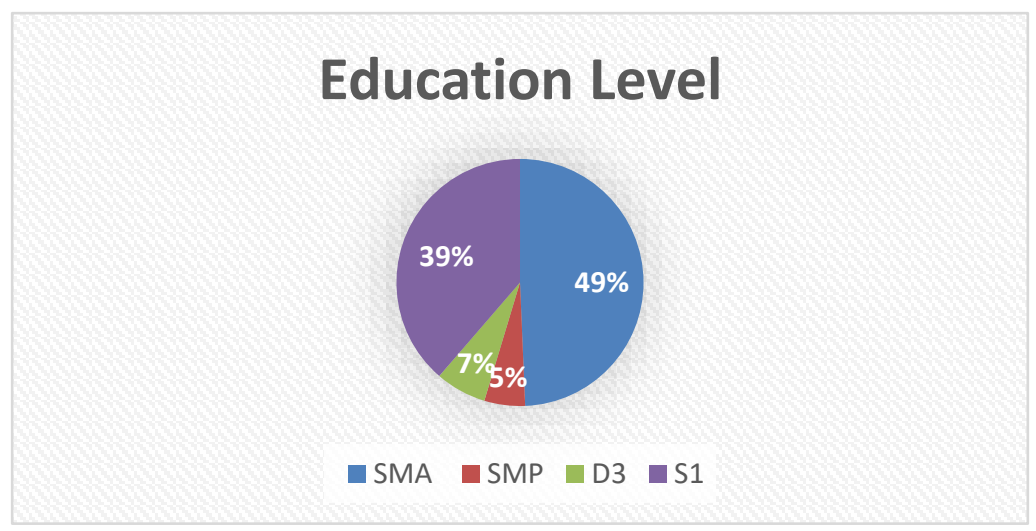

Table 2 shows that the education of Village-Owned Enterprise administrators in Sigi and Poso Regencies, Central Sulawesi Province is mostly SMA or equivalent as many as 37 people (49\%) while those who have junior high school education are 4 people (5\%), Diploma as many as 5 people (7\%), S1 as many as 29 people (39\%). Characteristics of respondents by age can be seen in Table 3.

Table 3.

Age of respondents

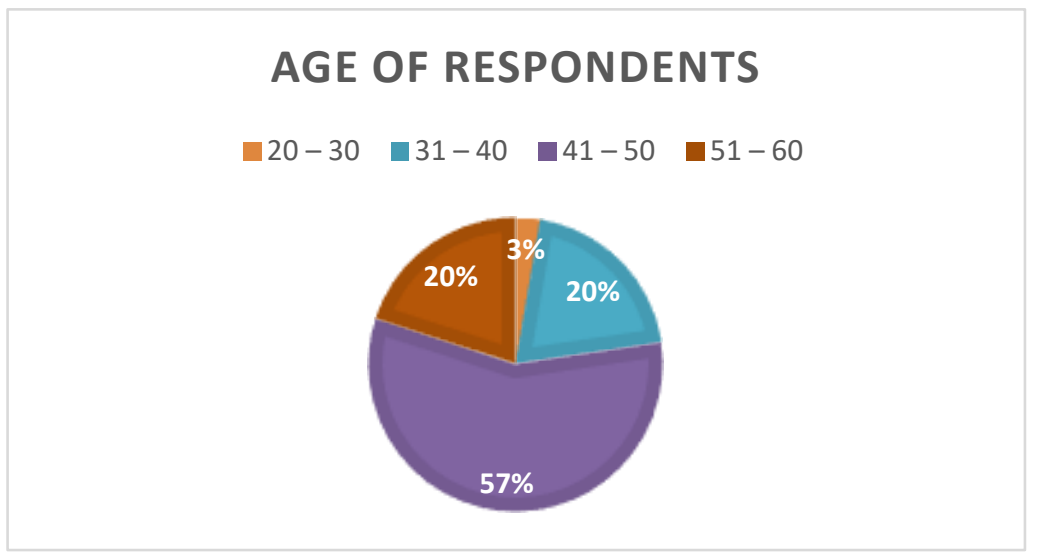

Table 3 shows that most Village-Owned Enterprise administrators have an age level of 41-50 years, amounting to 43 people (57\%) and 2 people with an age level of 20 -30 years old (3\%). Village-Owned Enterprise administrators aged 31-40 years are 15 people (20\%). 15 people aged 51-60 years $(20 \%)$. 


\section{Hypothesis test results}

Linear regression is one of the parametric statistical analysis tools which functions to analyze the linkages and relationships between different research variables, namely the dependent variable and the independent variable by requiring data consisting of several groups of observation or measurement results. The following are the results of linear regression analysis.

Table 4

Financial Literacy and Human Capital Regression Test Results on Village-Owned Enterprise Performance

\begin{tabular}{|c|c|c|c|c|c|}
\hline \multirow[t]{2}{*}{ No. } & \multirow[t]{2}{*}{ Independent Variable } & \multicolumn{4}{|c|}{ Dependent Variable (Y) } \\
\hline & & $\begin{array}{l}\text { Koefisien } \\
\text { Regresi (B) }\end{array}$ & $\begin{array}{l}\text { Test } \\
\text { Result T }\end{array}$ & $\begin{array}{l}\text { Probabilitas } \\
\text { (Sig T) }\end{array}$ & R Parsial \\
\hline 1. & Constanta (a) & 47.435 & 11.27 & & \\
\hline 2. & Financial Literacy and Performance & -0.067 & -0.586 & 0.560 & -0.069 \\
\hline 3 & Human Capital and Performance & 0.496 & 4.314 & 0.000 & 0.453 \\
\hline $\begin{array}{l}\text { Mul } \\
\text { Adj }\end{array}$ & $\begin{array}{l}\text { ple } \mathrm{R} \quad=0.471 \\
\text { ted R Square }=0.201\end{array}$ & $\begin{array}{c}\operatorname{are} \\
\alpha\end{array}$ & 22 & & \\
\hline
\end{tabular}

Table 4 illustrates the relationship between financial literacy and human capital on VillageOwned Enterprise performance. The constant value (a) is 47.435 , indicating that if financial literacy is neglected or worth 0 , then Accountability will be worth 47.435. The regression coefficient value is -0067, explaining that financial literacy variables have no effect on the financial performance of Village-Owned Enterprise. The human capital variable affects the performance of Village-Owned Enterprise. This can be seen from the regression coefficient value of 0.496 and significant at the $1 \%$ level.

\section{The relationship between financial literacy and the performance of Village-Owned Enterprise in Poso and Sigi Regencies}

The performance of Village-Owned Enterprises (Village-Owned Enterprise) plays an important role in the economic development of the community in the village. To improve the performance of Village-Owned Enterprise, it is very much determined by the resources owned by the Village-Owned Enterprise. One of the influencing factors is the financial literacy owned by Village-Owned Enterprise. Financial literacy is an essential thing that Village-Owned Enterprise managers must have. Financial literacy should be able to improve the performance of VillageOwned Enterprise by compiling plans to appropriate reporting (Cariola et al., 2020; Cosenz \& Bivona, 2020; De Marco et al., 2020; Ejdys, 2014; Florido et al., 2015; Santoro et al., 2019). However, the results of this study indicate that financial literacy has no impact on the performance of Village-Owned Enterprise. This can be interpreted that the ability of VillageOwned Enterprise administrators regarding financial literacy is not an important factor in improving Village-Owned Enterprise performance. Based on the observations obtained, there are many fat scores that affect the performance of this Village-Owned Enterprise. Among them are the absence of facilities that support the internet network, the Village-Owned Enterprise administrators do not understand the functions of the business entity so that the financial literacy owned by Village-Owned Enterprise administrators is not significant for the impact on Village-Owned Enterprise performance.

Village-Owned Enterprise management is a sector that should be important in the development of Village-Owned Enterprise. However, there is still management of village government in this context which is still weak in the accountability and transparency of VillageOwned Enterprise administrators. Financial literacy in Sigi village and even more so in Poso 
district is still far from perfect, because Village-Owned Enterprise administrators in SIGI and Poso in general cannot use the funds from the village accountably. This is due to the weak capacity of Village-Owned Enterprise administrators in managing Village-Owned Enterprise planning, implementation and financial reporting.

\section{The relationship between Human Capital and Village-Owned Enterprise performance in Poso and Sigi Regencies}

To develop a company in order to innovate or improve company performance is not only necessary with the accumulation of capital, but also the use of internal human resources. When a company has internal resources that are capable of this, it can make the company always innovate. When companies always innovate, this can improve their company's performance. This is in line with research conducted by (Abdul-Halim et al., 2019; Agostini, L., \& Nosella, 2017; Dabić et al., 2018; Gonzalez-Loureiro et al., 2017; Hult et al., 2004; Jansen et al., 2006; Kianto et al., 2017; Montequín et al., 2006; Ramadan et al., 2017; Rodrigues et al., 2011). The results of this study prove that the human capital of Village-Owned Enterprise administrators has an effect on Village-Owned Enterprise performance. This indicates that the community, including VillageOwned Enterprise administrators, has the potential to innovate so that it will have an impact on Village-Owned Enterprise performance.

\section{Conclusion}

Village-Owned Enterprise management is a sector that should be important in the development of Village-Owned Enterprise. However, there is still Village-Owned Enterprise management in this context that is still weak in the accountability and transparency of VillageOwned Enterprise administrators. Financial literacy in Sigi village and even more so in Poso district is still far from perfect, because Village-Owned Enterprise administrators in SIGI and Poso in general are unable to use village participation funds accountably. This is due to the weak capacity of Village-Owned Enterprise administrators in managing Village-Owned Enterprise planning, implementation and financial reporting. The results of this study prove that the human capital of Village-Owned Enterprise administrators has an effect on Village-Owned Enterprise performance. This indicates that the community, including Village-Owned Enterprise administrators, has the potential to innovate so that it will have an impact on Village-Owned Enterprise performance. Officials at the head of the Central Sulawesi provincial government should provide guidance to Village-Owned Enterprise administrators in developing financial literacy. Placement of educational qualifications (backround for economic graduates) can be taken into consideration in placing the Village-Owned Enterprise structure. Village-Owned Enterprise administrators need to pay attention to commodities from the region so that the results of these commodities can become superior potential.

\section{Acknowledgement}

Thank you to the Directorate of Research and Community Service, Directorate General of Research and Development Strengthening Ministry of Research, Technology and Higher Education of the Republic of Indonesia. This research was funded by the Directorate of Research and Community Service, Deputy of Strengthening Research and Development of the Ministry of Research and Technology / National Research and Development Agency in accordance with the Contract for Implementation of Community Service Programs Number SK for Research and Community Service Funding. Funding B / 87 / E3 / RA.00 / 2020 dated January 28, 2020, and Contract for Implementation of Community Service Programs for Fiscal Year 2020 Number 2851 / LL9 / AM / 2020. 


\section{Reference}

Abdul-Halim, H., Ahmad, N. H., Geare, A., \& Thurasamy, R. (2019). Innovation Culture in SMEs: The Importance of Organizational Culture, Organizational Learning and Market Orientation. Entrepreneurship Research Journal, 9(3), 1-14. https://doi.org/10.1515/erj2017-0014

Agostini, L., \& Nosella, A. (2017). Enhancing radical innovation performance through intellectual capital components. Journal of Intellectual Capital, 18(4), 789-806.

Agyei, S. K., Adam, A. M., \& Agyemang, O. S. (2019). Financial Literacy, Cultural Dominance, and Financial Well-Being of SME Owners in Ghana. Poverty and Public Policy, 11(3), 222-237. https://doi.org/10.1002/pop4.254

Cariola, A., Fasano, F., La Rocca, M., \& Skatova, E. (2020). Environmental sustainability policies and the value of debt in EU SMEs: Empirical evidence from the energy sector. Journal of Cleaner Production, 275. https://doi.org/10.1016/j.jclepro.2020.123133

Cosenz, F., \& Bivona, E. (2020). Fostering growth patterns of SMEs through business model innovation. A tailored dynamic business modelling approach. Journal of Business Research, February, 1-12. https://doi.org/10.1016/j.jbusres.2020.03.003

Dabić, M., Lažnjak, J., Smallbone, D., \& Švarc, J. (2018). Intellectual capital, organisational climate, innovation culture, and SME performance: Evidence from Croatia. Journal of Small Business and Enterprise Development. https://doi.org/10.1108/JSBED-04-2018-0117

De Marco, C. E., Martelli, I., \& Di Minin, A. (2020). European SMEs' engagement in open innovation When the important thing is to win and not just to participate, what should innovation policy do? Technological Forecasting and Social Change, 152(December 2019), 119843. https://doi.org/10.1016/j.techfore.2019.119843

Djuwita, D., \& Yusuf, A. A. (2018). Tingkat Literasi Keuangan Syariah Di Kalangan UMKM Dan Dampaknya Terhadap Perkembangan Usaha. Al-Amwal : Jurnal Ekonomi Dan Perbankan Syari'ah, 10(1). https://doi.org/10.24235/amwal.v10i1.2837

Ejdys, J. (2014). Future Oriented Strategy for SMEs. Procedia - Social and Behavioral Sciences, 156(April), 8-12. https://doi.org/10.1016/j.sbspro.2014.11.110

Florido, J. S. V., Adame, M. G., \& Tagle, M. A. O. (2015). Financial Strategies, the Professional Development of Employers and Performance of sme's (AGUASCALIENTES Case). Procedia Social and Behavioral Sciences, 174, 768-775. https://doi.org/10.1016/j.sbspro.2015.01.613

Gonzalez-Loureiro, M., Sousa, M. J., \& Pinto, H. (2017). Culture and innovation in SMEs: the intellectual structure of research for further inquiry. European Planning Studies, 25(11), 1908-1931. https://doi.org/10.1080/09654313.2017.1290052

Hult, G. T. M., Hurley, R. F., \& Knight, G. A. (2004). Innovativeness: Its antecedents and impact on business performance. Industrial Marketing Management, 33(5), 429-438. https://doi.org/10.1016/j.indmarman.2003.08.015

Jansen, J. J. P., Van Den Bosch, F. A. J., \& Volberda, H. W. (2006). Exploratory innovation, exploitative innovation, and performance: Effects of organizational antecedents and environmental moderators. Management Science, 52(11), 1661-1674. https://doi.org/10.1287/mnsc.1060.0576

Kianto, A., Sáenz, J., \& Aramburu, N. (2017). Knowledge-based human resource management practices, intellectual capital and innovation. Journal of Business Research, 81(December 2016), 11-20. https://doi.org/10.1016/j.jbusres.2017.07.018

Mabula, J. B., \& Ping, H. D. (2018). Use of technology and SME managers' financial literacy in developing economies. ACM International Conference Proceeding Series, 9(6), 145-152. https://doi.org/10.1145/3241748.3241765

Montequín, V. R., Fernández, F. 0., Cabal, V. A., \& Gutierrez, N. R. (2006). An integrated framework for intellectual capital measurement and knowledge management implementation in small and medium-sized enterprises. Journal of Information Science, 32(6), 525-538. https://doi.org/10.1177/0165551506067127 
Novi Yushita Amanita. (2017). Pentingnya Literasi Keuangan Bagi Pengelolaan Keuangan Pribadi. Jurnal Nominal, 6(15).

Owusu, J., Ismail, M. Bin, Osman, M. H. B. M., \& Kuan, G. (2019). Financial literacy as a moderator linking financial resource availability and SME growth in Ghana. Investment Management and Financial Innovations, 16(1), 154-166. https://doi.org/10.21511/imfi.16(1).2019.12

Ramadan, B. M., Dahiyat, S. E., Bontis, N., \& Al-dalahmeh, M. A. (2017). Intellectual capital, knowledge management and social capital within the ICT sector in Jordan. Journal of Intellectual Capital, 18(2), 437-462. https://doi.org/10.1108/JIC-06-2016-0067

Rodrigues, H. S., Dorrego, P. F., \& Jardon, C. M. F. (2011). The main intellectual capital components that are relevant to the product, process and management firm innovativeness. International Journal of Transitions and Innovation Systems, 1(3). https://doi.org/10.1504/ijtis.2011.042661

Santoro, G., Mazzoleni, A., Quaglia, R., \& Solima, L. (2019). Does age matter? The impact of SMEs age on the relationship between knowledge sourcing strategy and internationalization. Journal of Business Research, May, 1-9. https://doi.org/10.1016/j.jbusres.2019.05.021

Sugiarti, E. N., Diana, N., \& Mawardi, M. C. (2019). Peran Fintech Dalam Meningkatkan Literasi Keuangan Pada Usaha Mikro Kecil Menengah Di Malang. E-Jra, 8(4), 90-104.

Ye, J., \& Kulathunga, K. M. M. C. B. (2019). How does financial literacy promote sustainability in SMEs? A developing country perspective. Sustainability (Switzerland), 11(10), 1-21. https://doi.org/10.3390/su11102990 